\title{
Correspondence
}

\section{HLA-DR4 does not predispose to higher amounts of rheumatoid factors in healthy persons}

SiR, Several authors have reported the possible association between rheumatoid arthritis (RA) and the HLA-DR4 antigen. ${ }^{1-7}$ The most recent report has appeared in your columns. ${ }^{7}$ Some of the studies suggested that RA patients with HLA-DR4 more often had positive latex tests for rheumatoid factor, with higher titres than the other patients. ${ }^{3-6}$ HLA-DR4 might thus operate in relation to IgM rheumatoid factor production rather than rheumatoid arthritis. As healthy persons have low amounts of rheumatoid factors in their sera ${ }^{8}$ we therefore investigated whether those with HLA-DR4 had more rhematoid factors than the others.

Rheumatoid factors were measured quantitatively in the sera of 77 unrelated, healthy persons who had been tissue typed before (mean age 45 years, range $25-75 ; 47$ were women). We used a recently developed highly sensitive, enzyme linked, solid phase immunoassay measuring IgM rheumatoid factors with human IgG as an antigen. There are 5 dilutions in the normal range and the results obtained with this assay show an excellent correlation with those obtained with the latex test used in our laboratory ${ }^{6}$ (to be published). The overall incidence of HLA-DR4 was $21 \%$ in the 77 healthy controls; the 55 persons with 'low normal' titres had rather a higher frequency of HLA-DR4 (24\%) than the 22 with 'high normal' titres (14\%; NS). Although only small numbers of normals were tested, these results do not suggest that DR4 influences rheumatoid factor titres in healthy persons. Similarly, Rodriguez et al. ${ }^{9}$ did not find a relationship between HLA-DR4 and in-vitro IgM rheumatoid factor production in normals. In RA the relationship between DR4 and rheumatoid factors has not always been found; the study by Gran et $a l .{ }^{7}$ is the latest in this line. The difference might be, as these authors suggest, in the selection of the patients with seronegative RA during the different studies.

Division of Rheumatology,

THOMAS L. VISCHER Transplantation Immunology Unit, VLADIMIR VON FLIEDNER Division of Immunology,

Department of Medicine,

Hôpital Cantonal Universitaire

CH-1211 Geneva 4.

\section{References}

1 McMichael A J, Sasazuki T, McDevitt M O, Payne R O. Increased frequency of HLA-Cw3 and HLA-Dw4 in rheumatoid arthritis. Arthritis Rheum 1977; 20: 1037-42.

2 Stastny P. Association of the B-cell alloantigen DRw4 with rheumatoid arthritis. $N$ Engl J Med 1978; 298: 869-71.

3 Dobloug J H, Førre $\emptyset$, Kasse E, Thorsby E. HLA antigens and rheumatoid arthritis. Arthritis Rheum 1980; 23: 309-13.
4 Scherak O, Smolen J S, Mayr W R. Rheumatoid arthritis and B lymphocyte alloantigen HLA-DRw4.J Rheumatol 1980 7: 9-12.

5 Stastny P. Rheumatoid arthritis. In: Histocompatibility testing 1980. University of California: UCLA Press, 1980: 681-6.

6 Vischer T L, Multicentre Study. HLA-DR antigens in rheumatoid arthritis. Rheumatol Int 1981; 1: 111-3.

7 Gran J T, Husby G, Thorsby E. The association between rheumatoid arthritis and the HLA antigen DR4. Ann Rheum Dis 1983; 42: 292-6.

8 Kallerup H E, Egeskjold E M, Graudal H. IgG-, IgM- and IgArheumatoid factors in healthy adults and rheumatoid patients determined by an indirect immunofluorescence method. Scand $J$ Rheumatol 1979; 8: 1-9.

9 Rodriguez M A, Bankhurst A D, Williams Jr R C, Troup G M, Stastny P. Studies on the relationship between HLA DR4 and in vitro IgM rheumatoid factor production. Clin Immunol Immunopathol 1983; 27: 96-109.

\section{ESR in polymyalgia rheumatica and giant cell arteritis}

SIR, The recent report by Ellis and Ralston ${ }^{1}$ on the ESR in polymyalgia rheumatica (PMR) and giant cell arteritis (GCA) raises some interesting points. They found a normal ESR in $22.5 \%$ of cases at presentation, which is, as they state, a much higher incidence than has been found in other series. ${ }^{2-5}$ The value they adopted as elevated was $30 \mathrm{~mm} / \mathrm{h}$, and they quote that this was one of the diagnostic criteria which we used in our study of 108 patients with PMR and/or GCA ${ }^{6}{ }^{7}$ In fact the full version of our criteria read: 'An ESR of $30 \mathrm{~mm} / \mathrm{h}$ or greater or a C-reactive protein of greater than $6.4 \mu \mathrm{g} / 100 \mathrm{ml}$.' We did not come across one patient with clinical evidence of PMR and /or GCA with an ESR or CRP which was not raised on at least one occasion. In one case the ESR was normal on the 2 occasions it was measured $(20 \mathrm{~mm} / \mathrm{h}$ and $17 \mathrm{~mm} / \mathrm{h})$, but the CRP was elevated at 14.5 $\mu \mathrm{g} / 100 \mathrm{ml}$.

In 5 of the 108 patients a raised ESR was found when the investigation was repeated after an initially normal reading, while in another 5 patients a normal result was observed after the initial reading had been elevated. Two examples will illustrate the variation in the results.

Patient 1. Initial ESR $66 \mathrm{~mm} / \mathrm{h}, 16$ days later $14 \mathrm{~mm} / \mathrm{h}, 7$ days later $90 \mathrm{~mm} / \mathrm{h}$.

Patient 2. Initial ESR $9 \mathrm{~mm} / \mathrm{h}, 5$ days later $48 \mathrm{~mm} / \mathrm{h}, 7$ days later $74 \mathrm{~mm} / \mathrm{h}$.

Others have noted this day to day variation ${ }^{8}{ }^{9}$ and it is recommended that the test is performed several times when a normal result is found. Mallaya et al $^{10}$ have shown that the ESR can vary from hour to hour. In one of our patients the ESR was recorded at intervals after the daily dose of $15 \mathrm{mg}$ of prednisolone on the fourth day of treatment. The ESR fell from $48 \mathrm{~mm} / \mathrm{h}$ at $9.00 \mathrm{am}$ to $35 \mathrm{~mm} / \mathrm{h}$ at $10.00 \mathrm{am}$ and $11.00 \mathrm{am}$ and rose to $58 \mathrm{~mm} / \mathrm{h}$ at $12 \mathrm{mid}$-day. By $2.00 \mathrm{pm}$ it was $64 \mathrm{~mm} / \mathrm{h}$. Duplicate samples were set up on each occasion and there was never a difference of more than $2 \mathrm{~mm} / \mathrm{h}$ between specimens. 
The ESR returned to below $20 \mathrm{~mm} / \mathrm{h}$ on at least one occasion in all except 3 of the 101 cases in which a follow-up result was available, The elevation of the ESR was only modest in these 3 cases $(32,28,24 \mathrm{~mm} / \mathrm{h})$ and could be explained by continuing activity of the disease ( 2 cases) and a long-standing benign monoclonal gammopathy. The lowest recorded ESR was below $15 \mathrm{~mm} / \mathrm{h}$ in $95 \%$ of the 101 cases and $10 \mathrm{~mm} / \mathrm{h}$ or less in $76 \%$ of the patients. However, like Ellis and Ralston we observed several patients who were successfully managed on their symptoms alone and do not advocate that the dose of prednisone should be adjusted with the sole aim of keeping the ESR at a normal level. This may not prevent complications. One patient developed permanent loss of vision in one eye 2 months after the institution of corticosteroids, when she was completely symptom-free with an ESR of $3 \mathrm{~mm} / \mathrm{h}$. However, we feel that the ESR remains a most useful investigation in the diagnosis of PMR/GCA and recommend that, if a normal result is obtained initially, the ESR should be repeated at short intervals, as it may well be elevated subsequently. We should also recommend that the CRP should be measured in the suspected case with a normal ESR.

Department of Rheumatology,

J. G. JONES

Kings College Hospital,

London SE5

Department of Rheumatology,

B. L. HAZLEMAN

Addenbrooke's Hospital,

Cambridge CB2 2 QQ

\section{References}

1 Ellis M E, Ralston S. The ESR in the diagnosis and management of the polymyalgia rheumatica/giant cell arteritis syndrome. Ann Rheum Dis 1983; 42: 168-70.

2 Huston K A, Hunder G G, Lie J T, Kennedy R H, Elveback L R. Temporal arteritis. A 25 year epidemiological, clinical and pathologic study. Ann Intern Med 1978; 88: 162-7.

3 Hamilton $\mathbf{C} \mathbf{R}$, Shelley $\mathbf{W}$ M, Tumulty $\mathbf{P} A$. Giant cell arteritis: including temporal arteritis and polymyalgia rheumatica. Medicine 1971; 50: 1-27.

4 Fauchald P, Rygvold O, Øystese B. Temporal arteritis and polymyalgia rheumatica. Clinical and biopsy findings. Ann Intern Med 1972; 77: 845-52.

5 Graham E, Holland A, Avery A, Russell R W R. Prognosis in giant cell arteritis. $\mathrm{Br}$ Med $J$ 1982; 282: 269-71.
6 Jones J G, Hazleman B L. The prognosis and management of polymyalgia rheumatica. Ann Rheum Dis 1981; 40: 1-5.

7 Jones J G, Hazleman B L. Polymyalgia rheumatica and giant cell arthritis-a difficult diagnosis. J $R$ Col Gen Pract 1981; 31: 283-8.

8 Kinmont P D C, McCallum D I. The aetiology, pathology and course of giant cell arteritis. The possible role of light sensitivity. Br J Dermatol 1965; 77: 193-202.

9 Hunder G G, Sheps S G. Intermittent claudication and polymyalgia rheumatica associated with panarteritis. Arch Intern Med 1967; 119: 638-43.

10 Mallaya R K, Berry H, Mace B E W, de Beer F C, Pepys $M B$. Diurnal variation of erythrocyte sedimentation rate related to feeding. Lancet 1982; i: 389-90.

\section{Statistical power calculations}

SIR, When papers report a difference between 2 groups of patients they are expected to give the probability that such a difference (or an even bigger one) could have occurred by chance (the $p$ value). Reports of negative findings may provide important information, and these too should be supported by statistical calculations - in this case giving the probability that the failure to find a difference between patient groups may have occurred purely by chance (the 'power' of the investigation).

In the Annals for June 1983 you published 2 investigations which reported negative findings: the failure of hyperuricaemia to contribute to increased risk of vascular disease $^{1}$ and the failure of the type of onset of rheumatoid arthritis to predict subsequent outcome. ${ }^{2}$ The conclusions of both these papers are of interest, but they would have been strengthened by the inclusion of power calculations. ${ }^{3}$

Bone and Joint Research Unit, JOHN R. KIRWAN

The London Hospital Medical College,

London E1 2AD.

\section{References}

1 Darlington L G, Slack J, Scott J T. Vascular mortality in patients with gout and in their families. Ann Rheum Dis 1983; 42: 270-3.

2 Luukkainen R, Isomaki H, Kajander A. Prognostic value of the type of onset of rheumatoid arthritis. Ann Rheum Dis 1983; 42: 274-5.

3 Altman D G. Statistics and ethics in medical research, III. How large a sample? $\mathrm{Br}$ Med J 1980; 281: 1336-8.

\section{Book reviews}

Poliartrita Rheumatoidă. By V. Ciobanu and H. D. Boloşiu. Pp. 485. No price given. Academic Press: Bucharest. 1983.

This book is an excellent up-to-date account of our present knowledge of this disorder, the English summaries (pp. 475-485) giving a short abstract of the contents of the book. Illustrations are black-and-white, clear, and not over- numerous, references up to date from all countries, mostly in English. One criticism could be that 'Still's syndrome' is called juvenile rheumatoid arthritis, 'the equivalent form of rheumatoid disease' below 16 years of age. The book in general shows that the disorder otherwise seems much the same as we see in our patients here in Great Britain, and gives good wide references from the world's recent literature on the subject.

F. DUDLEY HART 